\title{
Mobile Money Use and Financial Inclusion for SME Entrepreneurs in East Africa
}

Victor Motta ${ }^{1}$

\footnotetext{
${ }^{1}$ EAESP-FGV / Fundação Getulio Vargas
} 


\section{MOBILE MONEY USE AND FINANCIAL INCLUSION FOR SME ENTREPENEURS IN EAST AFRICA}

Resumo: Inclusive financial systems in Africa are likely to benefit entrepreneurs leading small and medium-sized enterprises (SMEs) that are usually excluded from banking services. Mobile money technology may facilitate access to financial services for SMEs by reducing risks and transaction costs for financial service providers. Understanding the relationship between mobile money technology and financial inclusion in Africa is critical, as its banking system remains underdeveloped and less inclusive than other developing economies. As a result, the purpose of this study was to investigate the relationship between mobile money use and SME access to financial inclusion. Our findings indicate that both the purpose and the intensity of mobile money use have a positive impact on financial inclusion. The results of this study reveal a greater significant impact of mobile money use on the likelihood of access to bank loans and lines of credit.

Palavras-chave: mobile money, financial inclusion, entrepreneurship, SMEs

\section{Introduction}

Well-developed financial systems serve a critical purpose to financial development by offering savings, payment services, credit and risk management-related products to cater both individuals' and firms' wide variety of needs. Inclusive financial systems - allowing greater access to financial services - are likely to benefit small and medium-sized enterprises (SMEs) that are usually excluded from credit markets, not only forcing firms to rely on their limited earnings in the pursuit of potential growth opportunities, but also widening the persistence of income inequality and slower economic growth (Beck, Demirgüç-Kunt, \& Levine, 2007).

Financial inclusion, commonly defined as the use of formal financial services, such as bank account ownership, savings and access to bank loans (Demirgüç-Kunt, Klapper, Singer, \& Van Oudheusden, 2015), provides businesses with the possibility to have a safe place to store and saveCompared to other developing and emerging economies, specific banking characteristics make financial inclusion in Africa more challenging (Beck, Maimbo, Faye, \& Triki, 2011). For instance, the reliance formal financial institutions on hard information about businesses as opposed to soft information may have negative effects for riskier and more opaque SMEs as both the presence of information asymmetries and the absence of a sound contractual framework reduce the feasibility of small business lending (Beck, Senbet, \& Simbanegavi, 2015; Claessens \& van Horen, 2012). As a result, a large share of businesses in Africa are excluded from having access to formal financial services due to limited demand for transaction payments, overdrafts, savings and credit. Firms may also not have the necessary formal documentation that facilitates financial transactions, such as enterprise registration, due to high informality levels in the economy. These characteristics increase the need for technological innovative solutions.
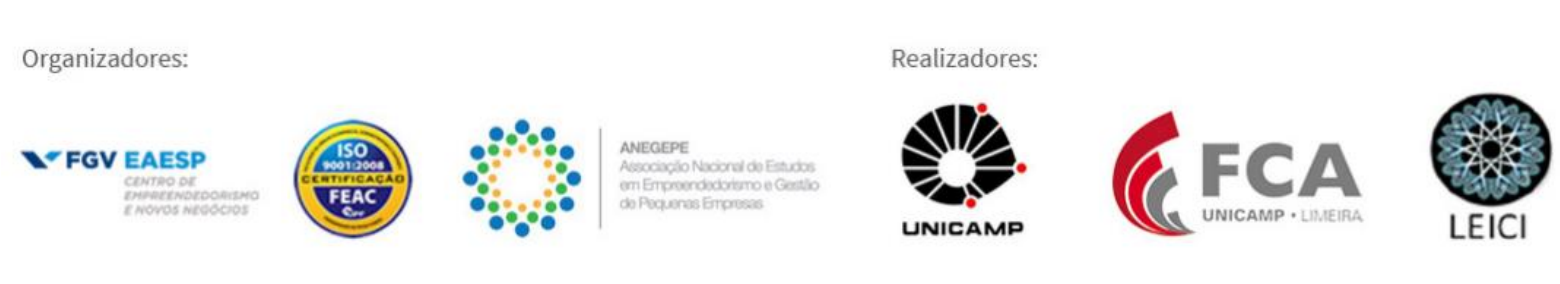
Technology can reduce risks and transaction costs for financial service providers by enabling the processing of smaller transactions, and as a result, increasing firm access to formal financial services. A growing number of individuals and firms are using new alternatives to traditional banking made possible by the rapid dissemination of innovation through mobile phones. Due to the prevalence of mobile phones in several regions in Africa, mobile financial service are often more accessible and affordable than financial services offered by traditional bank branches. Mobile money has allowed firms excluded from formal financial systems to conduct financial transactions in a cheaper and more secure manner, offering opportunities for a cost-effectively financial inclusion expansion. Mobile money services are currently used by firms to pay bills, suppliers, and employees as well as receive payments from customers (Heyer \& Mas, 2011).

Despite evidence on the importance of mobile technology as a tool for financial inclusion for households and informal microenterprises, little is known about mobile money as a tool for financial inclusion for SMEs that operate in formal markets. The purpose of this study was to investigate the relationship between mobile money use and SME access to financial inclusion using firm-level data for three countries in East Africa: Kenya, Tanzania and Uganda. We specifically focused on these economies due to their wider use of mobile money technology compared to other developing markets within and outside Africa (Demirguc-Kunt, Klapper, \& Singer, 2017). We used access to bank accounts, overdraft facility and bank loans or lines of credit as the three main indicators of financial inclusion.

SMEs may overcome constraints in banking services by increasing access to financial services through mobile phone based technology. African firms need greater levels of financial inclusion in order to expand their activities. Mobile money technology may facilitate access and use of financial services. Therefore, our study contributes to the recent mobile money literature since this technology may allow SMEs to reduce growth constraints, have better quality financial information and increase potential investment opportunities and access to external finance from formal financial institutions. To the best of our knowledge, this is the first study that assesses the impact of both purpose and intensity of mobile money use on the financial inclusion for SMEs in formal markets using a nationally representative firm-level data that allows for cross-country comparisons. In addition, we established a positive relationship between mobile money and financial inclusion that is robust across different measures of mobile money use.

The study proceeds as follows. Section 2 provides a review of the structure of the banking system in Africa, the role of mobile money to improve the financial system inclusiveness and firms' use mobile money. Section 3 presents the methods used, including a brief description of the dataset as well as the econometric technique and the main variables used in the study, while section 4 presents the results. Section 5 discusses the main findings, suggests future research areas of investigation and describes the main limitations of the study. Section 6 concludes the paper.

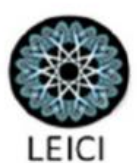




\section{Literature Review}

\section{Banking in Africa}

Although several significant improvements were implemented in financial systems in Africa within the past decades, including the expansion in the number of bank branches, ATMs, and agency banking, periods of rapid financial development maybe associate with an unstable and volatile monetary policy, in terms of money velocity and the money multiplier (Ndirangu \& Nyamongo, 2015). In addition, the provision of financial services tend to be less developed in African regions than in other developing economies. African countries are characterized by the presence of shallower financial systems compared to other developing markets, as measured by lower liquid liabilities, deposit to GDP and private credit to GDP ratios (Beck \& Cull, 2014).

In addition, banking systems in Africa are also less inclusive than in other developing markets in terms of access to and use of financial services. Account penetration in African countries, measured by both the number of bank branches and number of ATMs per either 10,000 or 100,000 adults, is much lower than in developing economies in other regions of the world (Allen et al., 2014). In other words, population density does not only have a strong correlation with financial development, but it is also more closely linked to bank branch penetration in Africa. As African SMEs cite access to external financing as the biggest growth obstacle, compared to businesses in other developing and emerging markets, they tend to be more constrained by the lack of proper access to a bank loan or line of credit, a major obstacle for firm growth (Demirguc-Kunt \& Klapper, 2012). As a result, informal sources of borrowing, especially through family and friends, is widespread in African economies (Klapper \& Singer, 2015)

\section{Mobile Money and Financial Inclusion}

Bank branch penetration and the outreach of Africa's financial system remain low due to challenges related to achieving a viable scale in sparsely populated and low-income areas. As a result, technological advances in mobile telephony have facilitated financial development outside major cities by enabling household use of financial services in areas with low population density. Both access to and use of mobile telephone technology have dramatically increased over the past two decades in Africa. Mobile phone technologies represent an enormous advancement in telecommunications infrastructure, allowing individuals to communicate with other individuals, and obtain information from markets and services. In addition, mobile phones have greatly reduced both search and communication costs, allowing tangible economic benefits such as enhancing access to information and efficiency in obtaining information in agricultural and labor markets as well as improvements in consumer and producer welfare (Aker \& Mcclelland, 2013).

A recent emerging trend in mobile telephony is the development of mobile phonebased services and products that facilitate financial transactions via mobile phone, including
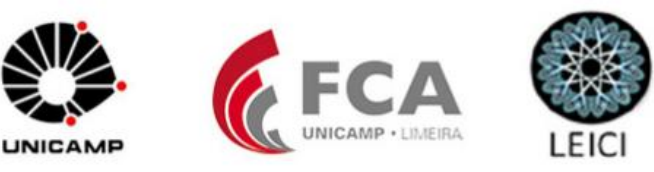
the purchase of airtime, paying bills and transferring money among individuals. Through mobile money, users can send remittances to other users or non-users, pay directly for goods and services, make deposits and withdrawals of cash and act as a savings instrument for unbanked households. In parallel with the diffusion of mobile money use, recent studies have investigated the impact of mobile money for households. The increasing use of mobile money has been shown to drastically reduce travel costs (Bangens \& Söderberg, 2011), increase security (Wright et al., 2014), increase remittances and savings for unpredictable events, such as health emergencies, among high-risk groups (Ky, Rugemintwari, \& Sauviat, 2017), and enhance financial inclusion and women's economic empowerment (Batista \& Vicente, 2012; Morawczynski \& Pickens, 2009; Munyegera \& Matsumoto, 2016).

\section{Firm Access and Use of Mobile Money}

Although there is an increasing body of literature examining the impact of mobile money usage on household economic decision-making, evidence on the relationship between mobile money and firms is at its infant stages. Higgins et al. (2012) found that SMEs in Kenya had a higher rate of mobile money adoption and financial transactions, such as paying utility bills, employee wages and suppliers as well as receiving payments from customers, sometimes in large amounts over long distances. Bangens and Söderberg (2011) present a preliminary picture of mobile money usage by micro and small-sized firms in the informal sector. Anecdotal evidence from the entrepreneurs reports indicate that mobile money may decrease transaction costs, and as a result, entrepreneurs may spend more time running their businesses and sell more. More recent studies examined firm characteristics that are likely to adopt mobile money. Gosavi (2015) found that small firms and firms that have bank accounts were more likely to use mobile money services.

However, the impact of mobile money on the formal private sector has large potential for research, as several questions on the relationship between mobile money and financial inclusion remain unanswered. Our study extends extant research and previous contributions by investigating the impact of mobile money use, including the purpose and intensity of use, on different financial inclusion indicators, such as access to bank accounts, overdraft facilities and loans or lines of credit from formal financial institutions. This is an important issue in Africa, as its banking system remains underdeveloped and less inclusive than other developing economies. We anticipate a positive effect between access and use of mobile money and financial inclusion for SMEs operating in the formal economy.

\section{Methods}

The data source used in this study consisted of cross-sectional firm-level data for Kenya, Tanzania and Uganda collected by the World Bank Enterprise Surveys (WBES) in fiscal year 2012. The sample used for analysis covers 2,356 firms in both the manufacturing and service sectors. Among the total, 781 businesses come Kenya while the number of businesses from Tanzania and Uganda comprises 813 and 762 enterprises, respectively. WBES defines SMEs as formal enterprises having the number of full time employees
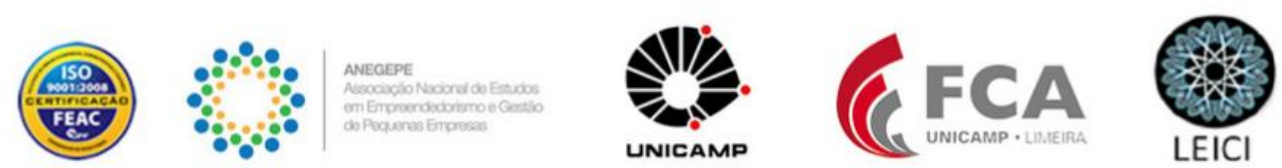
between 5 and 99 workers (inclusive). Accordingly, the sample cover 1,777 SMEs: 554 in Tanzania, 644 in Uganda and 579 in Kenya. We chose these three countries in East Africa due to their highest adoption rate of mobile money access and usage (Demirguc-Kunt et al., 2017). The same set of questions on the use of mobile money was included in the recent surveys conducted in Zambia, Ivory Coast and Zimbabwe. However, they were not included in our analysis since the adoption rate was low, and as a result, the sample size of mobile money SME users was small.

WBES are used to create statistically significant business environment indicators that are comparable across nations as well as building a panel of enterprise data allowing the tracking of changes in the business environment over time. Through extensive interviews with firms in the manufacturing and service sector, the enterprise surveys capture firm access and use of mobile money for financial transactions, such as the percentage of total labor costs, raw material and utilities paid using mobile money as well as the percentage of annual sales received through mobile money. In addition, the surveys provide the main benefits and obstacles for using mobile money for financial transactions, including the reduction of costs and risks of financial transaction and satisfaction of customers and suppliers' requests. Conversely, high fees, large payments difficult to undertake using mobile money, nonadoption by customers and suppliers, difficulty to implement in the business operations and lack of knowledge are among the main obstacles that impede firms from using the technology.

In addition, the survey measures access to finance, including financial inclusion indicators, and collects data on a broad array of topics that impact SMEs, including infrastructure, labor, crime, corruption, business environment, and business perceptions on the biggest obstacles to enterprise growth, and the relative importance of various constraints to increasing employment, productivity and several performance measures. The WBES used a standardized questionnaire instrument and stratified random sampling that generated a representative sample of nonagricultural and nonfinancial businesses in in Kenya, Tanzania and Uganda. The surveys are stratified according to sector of activity (manufacturing, and service), geographical location and firm size. The sample was stratified into eight manufacturing industries and two service industries. Weights were also used to ensure sample representativeness of the non-agricultural, non-mining private sector of the economy.

\section{Data Analysis}

In order to evaluate the impact of both access and use of mobile money technology on financial inclusion, we perform logit estimations by maximum likelihood through the following equation:

Financial Inclusion $=\beta_{1}+\beta_{2}($ Mobile Money $)+\beta_{3}($ Firm Characteristics $)+$ $\beta_{4}($ Owner Characteristics $)+\beta_{5}($ Country - Level Variables $)+\varepsilon$

Our main empirical specifications focus on three dichotomous indicators of financial inclusion as dependent variables: having a checking or savings account, overdraft facility and

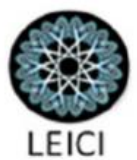


bank loan or line of credit from a formal financial institution. A value of 1 indicates that SMEs have access to each of these indicators individually and 0 otherwise.

\section{Explanatory Variables}

The main explanatory dummy variable, mobile money, refers to access to mobile money technology, and takes the value of 1 if a firm has used mobile money for any financial transaction and 0 otherwise. We also consider measures of mobile money use in order to capture the purpose of use. Employees is a dummy variable that takes the value of 1 if firms used mobile money to pay its employees. Suppliers is a dummy variable that takes the value of 1 if firms used mobile money to pay its suppliers. Utility is a dummy variable that takes the value of 1 if firms used mobile money to pay utility bills. Finally, customers is a dummy variable that takes the value of 1 if firms used mobile money to receive payments from customers.

\section{Control Variables}

Consistent with previous literature, the estimated econometric models utilized several control variables that mainly referred to firm characteristics (Becchetti \& Trovato, 2002; Nichter \& Goldmark, 2009; Söderbom \& Teal, 2001). To account for quality of the SME project, we use sales export, defined as the proportion of the establishment's sales that were destined as direct and indirect exports (Love \& Roper, 2015) as selling in international markets may signal better quality projects, efficiency and competitiveness to domestic investors and creditors (Bridges \& Guariglia, 2006). We also use quality certification, a dummy variable that captures whether the firm has an internationally recognized certification quality, such as ISO, as a proxy for the firm quality (Goedhuys \& Sleuwaegen, 2013). Given the complementary nature of mobile money and e-mail use, technology use is controlled for by e-mail communication, a dummy variable that indicates whether a firm uses e-mail to interact with clients or suppliers.

We also controlled for firm age using a continuous log transformed variable and firm size using a log transformed variable that indicates the number of employees (from 5 to 99 employees). To account for firm location, we included two city dummy variables, City $250 \mathrm{~K}$ to 1 million and City $50 \mathrm{~K}$ to $250 \mathrm{~K}$, representing the population size of the city in which the firm is located. In addition, we used variable foreign ownership to indicate the percentage of the firm owned by private foreign individuals, companies or organizations. In terms of owner characteristics, we have also included managerial experience, a continuous variable for the top manager's years of managerial experience and a women-owned SME, a dummy variable that indicates whether there is a female owner amongst the owners of the firm as prior research suggests the presence of gender differences in financial inclusion (Aterido \& Hallward-Driemeier, 2011).

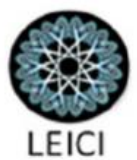




\section{Results}

Among East African SMEs in the dataset, $47 \%$ use mobile money for any of its financial transactions while $54 \%$ do not. The use of mobile for financial transactions range from $42 \%$ in Tanzania to $45 \%$, and 50\% in Uganda and Kenya, respectively. Table 1 presents reasons for using mobile money. The main reasons cited for SME mobile money use were to reduce the time spent in financial transactions, reduce the costs and risks of financial transactions and satisfy customers' request. In addition, SMEs cited the main reasons for not using mobile money, such as payments are large to use mobile money, customers and suppliers do not use mobile money, and high fees. Among all SMEs in the dataset, including firms that do not use mobile money, $8 \%$ of SMEs use mobile money to pay employees $(5 \%$ in Tanzania, $10 \%$ in Uganda and $8 \%$ in Kenya); $20 \%$ use to pay suppliers (17\% in Tanzania, $22 \%$ in Uganda and $21 \%$ in Kenya); $18 \%$ use to pay utility bills (22\% in Tanzania, $15 \%$ in Uganda and $17 \%$ in Kenya); $30 \%$ of SMEs use mobile money to receive payments from customers (23\% in Tanzania, 29\% in Uganda and 38\% in Kenya).

The descriptive statistics for the main firm characteristics are presented in table 2.

In terms of financial inclusion, overall, an average of $86 \%$ of SMEs have a checking or savings account, $16 \%$ have an overdraft facility and $25 \%$ have a loan and line of credit from a formal financial institution. In addition, an average of $13 \%$ of sales were direct and indirect exports SMEs have also an average of 20 full-time employees and are 16 years old. Among these firms, on average, $7 \%$ have foreign ownership, 53\% communicate with clients and suppliers by e-mail, and $19 \%$ have an internationally recognized quality certification, such as ISO. In addition, 34\% of SMEs have women ownership and they own on average $49 \%$ of the firms. Top managers have an average value of 14 years of experience, while $14 \%$ of SMEs have female top managers.

Table 3 shows the logit results regarding the impact of using mobile money financial transactions on the likelihood of financial inclusion for SMEs. Overall, we found a positive impact of mobile money use on financial inclusion. The results show statistically significant association between mobile money and access to checking/savings accounts (column 1), access to overdraft facility (column 2) and access to loans and/or lines of credit from formal financial institutions (column 3). More specifically, our findings indicate that SMEs with access to mobile money are more likely to have checking/savings account, overdraft facility and bank loans or lines of credit by $61 \%, 38 \%$ and $57 \%$, respectively.

Table 4 and table 5 extend the analysis by exploring the relationship between the likelihood of financial inclusion and the purpose of mobile money use. Table 4 presents the results of the impact of mobile money use to pay both employees and suppliers on the likelihood of financial inclusion. Our findings indicate a positive association between mobile money use to pay employees on financial inclusion, although the relationship is only statistically significant for access to bank loans and lines of credit. SME use of mobile money to pay employees increases the likelihood to obtain loans or lines of credit from formal financial institutions by a factor of two. Likewise, mobile money use to pay suppliers was

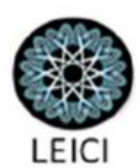


positively associated with financial inclusion. The results were statistically significant for access to checking/savings account and bank loans/line of credit. We found that SMEs using mobile money to pay suppliers are $48 \%$ and $53 \%$ more likely to have access to checking/ savings accounts and obtain loans or lines of credit from formal financial institutions, respectively.

Table 5 presents the results of the impact of mobile money use to pay firm utility bills and receive payments from customers. Similar to the previous findings, our results indicate a positive association between mobile money use and the likelihood of financial inclusion. The results show statistical significance for both use of mobile money to pay utilities and obtain payments from customers taking into account all three indicators of financial inclusion. Overall, we found that SMEs using mobile money to pay utility bills are $39 \%$ and $62 \%$ more likely to have access to an overdraft facility and a bank loan or line of credit, respectively, and twice more likely of having access to a bank checking or savings account. In addition, using mobile money to receive payments from customers was also found to increase the likelihood of having a bank account by $61 \%$, overdraft facility by $54 \%$ and bank loan or line of credit by $45 \%$.

In addition, we overall found SME size, measured by the number of employees, to have a positive and significant impact on financial inclusion. Findings also indicate a positive and significant relationship between firm age and financial inclusion in terms of access to overdraft facility and bank loans/lines of credit. E-mail use to communicate with clients or suppliers, a proxy for technology, years of top manager experience, and women-owned SMEs were associated with positive likelihood of financial inclusion in terms of having access to bank loans, although foreign ownership was negatively associated with the likelihood of financial inclusion.

\section{Discussion}

The purpose of our study was to investigate the impact of mobile money use, including the purpose and intensity of use, on different financial inclusion indicators, such as access to bank accounts, overdraft facilities and loans or lines of credit from formal financial institutions. Overall, our findings indicate that mobile money use increase the likelihood of SME financial inclusion. We also found statistically significant effects indicating that womenowned SMEs are on average $45 \%$ more likely to have access to loans and lines of credit from formal financial institutions. This is consistent with previous findings (Aterido, Beck, \& Iacovone, 2013; Islam \& Amin, 2016). A potential explanation for the higher likelihood of access to external finance may indicate that women-owned SMEs are of superior quality, in part due to the lower number of women-owned SMEs in East Africa. Using WBES data, for instance, one third of SMEs are owned by women although only 14\% of all SMEs have a female top manager. Another possible explanation to the greater of access to bank loans and lines of credit may be due to potential selection bias. Although enterprises with female ownership tend to be young and small, and women entrepreneurs are less likely to manage SMEs with sole proprietorships, they are more likely to innovate.

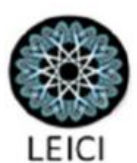


The findings from this study could inform the potential impact of new forms of technology on financial inclusion for enterprises participating in formal markets. Since mobile money technology may have similar attributes as other forms of technologies, policymakers may be able to make inferences about general aspects of technology using studies that assess the interaction between mobile money and the formal business private sector. Innovation, through mobile money and other technologies, may integrate financial systems in Africa and assist in the diffusion of financial inclusion to individuals, informal microenterprises and SMEs participating in the formal economy. Particularly in the case of SMEs, wider access to mobile money may facilitate keeping electronic records of financial transactions, allowing firms to reduce the high cost of cash in terms of risks involving security, leakages and transportation.

In addition, keeping a record of financial transactions may assist entrepreneurs in the design of adequate balance sheet, income and cash flow statements. In turn, having financial statements of greater quality may facilitate their validation through external auditing. This is an important step for greater access to external financing since SMEs with audited financial statements are not only more likely to obtain loan contracts, but it is also a necessary condition for businesses planning to issue equity (Ou \& Haynes, 2006; Van Caneghem \& Van Campenhout, 2012). High levels of leverage may prevent SMEs from obtaining other loans, so lack of equity for SMEs is an important constraint on bank finance. Equity can be a beneficial financing source for enterprises in their early years and for SMEs with high-risk profiles.

\section{Conclusion}

Inclusive financial systems in Africa are likely to benefit small and medium-sized enterprises (SMEs) that are usually excluded from banking services. Mobile money technology may facilitate access to financial services for SMEs by reducing risks and transaction costs for financial service providers. As a result, the purpose of this study was to investigate the relationship between mobile money use and SME access to financial inclusion. Our findings indicate that both the purpose and the intensity of mobile money use have a positive impact on three measures of financial inclusion: access to current or savings account, access to an overdraft facility and access to loan or line of credit from a formal financial institution. The results of this study reveal a greater significant impact of mobile money use on the likelihood of access to bank loans and lines of credit. As a result, further investigations to understand the relationship between mobile money use and the terms of loan contracts, such as maturity, interests and the size of loans, are critical in order to alleviate major growth constraints of African SMEs in accessing external financing.

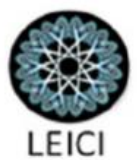




\section{References}

Aker, J. C., \& Mcclelland, A. (2013). How do Electronic Transfers Compare? Evidence from a Mobile Money Cash Transfer Experiment in Niger.

Allen, F., Carletti, E., Cull, R., Qian, J. Q., Senbet, L., \& Valenzuela, P. (2014). The African Financial Development and Financial Inclusion Gaps. Journal of African Economies, 23(5), 614-642. http://doi.org/10.1093/jae/eju015

Aterido, R., Beck, T., \& Iacovone, L. (2013). Access to Finance in Sub-Saharan Africa: Is There a Gender Gap? World Development, 47, 102-120. http://doi.org/10.1016/j.worlddev.2013.02.013

Aterido, R., \& Hallward-Driemeier, M. (2011). Whose business is it anyway?: Closing the gender gap in entrepreneurship in Sub-Saharan Africa. Small Business Economics, 37, 443-464. http://doi.org/10.1007/s11187-011-9375-y

Bangens, L., \& Söderberg, B. (2011). Mobile Money Transfers and Usage Among Micro- and Small Businesses in Tanzania.

Batista, C., \& Vicente, P. C. (2012). Introducing Mobile Money in Rural Mozambique: Evidence from a Field Experiment. Nova Africa, (1301), 43. http://doi.org/10.2139/ssrn.2384561

Becchetti, L., \& Trovato, G. (2002). The Determinants of Growth for Small and Medium Sized Firms . The Role of the Availability of External Finance. Small Business Economics, 19(4), 291-306.

Beck, T., \& Cull, R. (2014). SME finance in Africa. Journal of African Economies, 23(5), 583-613. http://doi.org/10.1093/jae/eju016

Beck, T., Demirgüç-Kunt, A., \& Levine, R. (2007). Finance, inequality and the poor. Journal of Economic Growth, 12(March), 27-49. http://doi.org/10.1007/s10887-007-9010-6

Beck, T., Demirgüç-Kunt, A., \& Singer, D. (2013). Is Small Beautiful? Financial Structure, Size and Access to Finance. World Development, 52, 19-33. http://doi.org/10.1016/j.worlddev.2013.05.014

Beck, T., Maimbo, S., Faye, I., \& Triki, T. (2011). Financing Africa: through the crisis and beyond. Retrieved from https://openknowledge.worldbank.org/handle/10986/2355

Beck, T., Senbet, L., \& Simbanegavi, W. (2015). Financial Inclusion and Innovation in Africa: An Overview. Journal of African Economies, 24, i3-i11. http://doi.org/10.1093/jae/eju031

Bridges, S., \& Guariglia, A. (2006). Financial Constraints, Global Engagement, and Firm Survival in the UK: Evidence from Micro Data. SSRN Electronic Journal, 55(4), 444465. http://doi.org/10.2139/ssrn.945595 
Claessens, S., \& van Horen, N. (2012). Being a foreigner among domestic banks: Asset or liability? Journal of Banking and Finance, 36(5), 1276-1290.

http://doi.org/10.1016/j.jbankfin.2011.11.020

Demirguc-Kunt, A., \& Klapper, L. (2012). Financial inclusion in Africa: an overview (No. 6088). Policy Research Working Paper. Retrieved from http://papers.ssrn.com/sol3/papers.cfm?abstract_id=2084599

Demirguc-Kunt, A., Klapper, L., \& Singer, D. (2017). Financial inclusion and inclusive growth: A review of recent empirical evidence (Policy Research Working Pper No. 8040).

Demirgüç-Kunt, A., Klapper, L., Singer, D., \& Van Oudheusden, P. (2015). The Global Findex Database 2014: Measuring Financial Inclusion around the World. World Bank Policy Research Working Paper 7255, (April), 1-88. http://doi.org/10.1596/1813-94507255

Goedhuys, M., \& Sleuwaegen, L. (2013). The Impact of International Standards Certification on the Performance of Firms in Less Developed Countries. World Development, 47, 87101. http://doi.org/10.1016/j.worlddev.2013.02.014

Gosavi, A. (2015). The Next Frontier of Mobile Money Usage-Firms-Evidence from SubSaharan Africa. In 19th Annual Western Hemispheric Trade Conference Proceedings (pp. 139-164). http://doi.org/10.1080/08853908.2015.1045638

Heyer, A., \& Mas, I. (2011). Fertile Grounds for Mobile Money: Towards a Framework for Analyzing Enabling Environments. Enterprise Development and Microfinance, 22(1), 115. http://doi.org/10.3362/1755-1986.2011.005

Higgins, D., Kendall, J., \& Lyon, B. (2012). Mobile Money Usage Patterns of Kenyan Small and Medium Enterprises, 7(2), 67-81.

Howorth, C., \& Moro, A. (2010). Trustworthiness and interest rates: an empirical study of Italian SMEs. Small Business Economics, 39(1), 161-177. http://doi.org/10.1007/s11187-010-9285-4

Islam, A., \& Amin, M. (2016). Women Managers and The Gender-Based Gap in Access to Education: Evidence from Firm-Level Data in Developing Countries. Feminist Economics, 22(3), 127-153. http://doi.org/10.1080/13545701.2015.1081705

Klapper, L., \& Singer, D. (2015). The role of informal financial services in Africa. Journal of African Economies, 24, i12-i31. http://doi.org/10.1093/jae/eju027

Ky, S., Rugemintwari, C., \& Sauviat, A. (2017). Does Mobile Money Affect Saving Behaviour? Evidence from a Developing Country. Journal of African Economies, (February 2018), 1-36. http://doi.org/10.1093/jafeco/ejx028

Love, J. H., \& Roper, S. (2015). SME innovation, exporting and growth: A review of existing evidence. International Small Business Journal, 33(1), 28-48. 
http://doi.org/10.1177/0266242614550190

Morawczynski, O., \& Pickens, M. (2009). Poor People Using Mobile Financial Services: Observations on Customer Usage and Impact from M-PESA. Cgap, (August), 4. Retrieved from http://www.cgap.org/publications/poor-people-using-mobile-financialservices

Munyegera, G. K., \& Matsumoto, T. (2016). Mobile Money, Remittances, and Household Welfare: Panel Evidence from Rural Uganda. World Development, 79(25101002), 127137. http://doi.org/10.1016/j.worlddev.2015.11.006

Ndirangu, L., \& Nyamongo, E. M. (2015). Financial innovations and their implications for monetary policy in Kenya. Journal of African Economies, 24(February 2018), i46-i71. http://doi.org/10.1093/jae/eju029

Nichter, S., \& Goldmark, L. (2009). Small Firm Growth in Developing Countries. World Development, 37(9), 1453-1464. http://doi.org/10.1016/j.worlddev.2009.01.013

Ou, C., \& Haynes, G. W. (2006). Acquisition of additional equity capital by small firms Findings from the national survey of small business finances. Small Business Economics, 27(2-3), 157-168. http://doi.org/10.1007/s11187-006-0009-8

Söderbom, M., \& Teal, F. (2001). Firm size and human capital as determinants of productivity and earnings (WPS 2001 No. 9). Retrieved from http://core.kmi.open.ac.uk/download/pdf/6280477.pdf

Van Caneghem, T., \& Van Campenhout, G. (2012). Quantity and quality of information and SME financial structure. Small Business Economics, 39(2), 341-358. http://doi.org/10.1007/s11187-010-9306-3

Wright, R., Tekin, E., Topalli, V., McClellan, C., Dickinson, T., \& Rosenfeld, R. (2014). Less Cash, Less Crime: Evidence from the Electronic Benefit Transfer Program. Retrieved from http://www.nber.org/papers/w19996.pdf 


\section{Tables}

Table 1: Main Reasons to Use Mobile Money for Financial Transactions (\%)

Reduce costs of financial transactions

Reduce the time spent in financial transactions

Reduce the risks in financial transactions

Satisfy suppliers' request

Satisfy costumers' request

Align with competitors' use

$\begin{array}{llll}\text { Tanzania } & \text { Uganda } & \text { Kenya } & \text { East Africa } \\ 26 & 25 & 8 & 19 \\ 58 & 40 & 45 & 47 \\ 2 & 10 & 13 & 9 \\ 2 & 10 & 6 & 6 \\ 11 & 13 & 26 & 17 \\ 2 & 3 & 2 & 2\end{array}$

Table 2: Descriptive Statistics Explanatory Variables

\begin{tabular}{|c|c|c|c|c|}
\hline & Mean & Standard Deviation & Minimum & Maximum \\
\hline \multicolumn{5}{|l|}{ Tanzania } \\
\hline Firm Size(Employees) & 19.06 & $(18.59)$ & 5 & 95 \\
\hline Firm Age & 14.74 & $(9.62)$ & 1 & 60 \\
\hline Foreign Ownership (\%) & 3.54 & $(15.57)$ & 0 & 100 \\
\hline Women-Owned SME (\%) & 55.34 & $(36.11)$ & 1 & 100 \\
\hline Years of Experience & 13.23 & $(7.98)$ & 1 & 45 \\
\hline \multicolumn{5}{|l|}{ Uganda } \\
\hline Firm Size(Employees) & 17.37 & $(18.57)$ & 5 & 98 \\
\hline Firm Age & 14.14 & $(9.58)$ & 1 & 86 \\
\hline Foreign Ownership (\%) & 11.03 & $(30.17)$ & 0 & 100 \\
\hline Women-Owned SME (\%) & 55.17 & $(33.79)$ & 0 & 100 \\
\hline Years of Experience & 13.37 & $(8.10)$ & 1 & 41 \\
\hline \multicolumn{5}{|l|}{ Kenya } \\
\hline Firm Size(Employees) & 24.53 & $(22.06)$ & 5 & 98 \\
\hline Firm Age & 20.91 & $(16.33)$ & 1 & 107 \\
\hline Foreign Ownership (\%) & 5.86 & $(20.15)$ & 0 & 100 \\
\hline Women-Owned SME (\%) & 40.69 & $(26.41)$ & 0 & 100 \\
\hline Years of Experience & 17.69 & $(10.72)$ & 1 & 57 \\
\hline \multicolumn{5}{|l|}{ East Africa } \\
\hline Firm Size(Employees) & 20.23 & $(20.01)$ & 5 & 98 \\
\hline Firm Age & 16.58 & $(12.62)$ & 1 & 107 \\
\hline Foreign Ownership (\%) & 7.05 & $(23.46)$ & 0 & 100 \\
\hline Women-Owned SME (\%) & 48.55 & $(31.92)$ & 0 & 100 \\
\hline Years of Experience & 14.76 & $(9.24)$ & 1 & 57 \\
\hline
\end{tabular}


Table 3: The Impact of Mobile Money Access on Financial Inclusion

\begin{tabular}{|c|c|c|c|}
\hline & $\begin{array}{l}\text { Checking or Savings } \\
\text { Account }\end{array}$ & $\begin{array}{l}\text { Overdraft } \\
\text { Facility }\end{array}$ & $\begin{array}{l}\text { Bank Loans or Lines } \\
\text { of Credit }\end{array}$ \\
\hline Mobile Money Access & $\begin{array}{l}1.607^{* * *} \\
(0.279)\end{array}$ & $\begin{array}{l}1.384^{* *} \\
(0.221)\end{array}$ & $\begin{array}{l}1.567^{* * *} \\
(0.206)\end{array}$ \\
\hline Quality Certification & $\begin{array}{l}1.097 \\
(0.291)\end{array}$ & $\begin{array}{l}1.148 \\
(0.225)\end{array}$ & $\begin{array}{l}1.173 \\
(0.203)\end{array}$ \\
\hline$\%$ Export Sales & $\begin{array}{l}0.996 \\
(0.00275)\end{array}$ & $\begin{array}{l}1.004 \\
(0.00273)\end{array}$ & $\begin{array}{l}1.003 \\
(0.00220)\end{array}$ \\
\hline Firm Size & $\begin{array}{l}1.606^{* * *} \\
(0.207)\end{array}$ & $\begin{array}{l}1.578^{* * *} \\
(0.159)\end{array}$ & $\begin{array}{l}1.343^{* * *} \\
(0.119)\end{array}$ \\
\hline Firm Age & $\begin{array}{l}1.025 \\
(0.129)\end{array}$ & $\begin{array}{l}1.329^{* *} \\
(0.179)\end{array}$ & $\begin{array}{l}1.263^{* *} \\
(0.134)\end{array}$ \\
\hline City $250 \mathrm{~K}$ to 1 million & $\begin{array}{l}0.968 \\
(0.170)\end{array}$ & $\begin{array}{l}1.128 \\
(0.194)\end{array}$ & $\begin{array}{l}1.542^{* * *} \\
(0.211)\end{array}$ \\
\hline City $50 \mathrm{~K}$ to $250 \mathrm{~K}$ & $\begin{array}{l}1.693 \\
(1.860)\end{array}$ & $\begin{array}{l}1.353 \\
(1.297)\end{array}$ & $\begin{array}{l}0.304 \\
(0.305)\end{array}$ \\
\hline Foreign Ownership & $\begin{array}{l}1.000 \\
(0.00459)\end{array}$ & $\begin{array}{l}0.994 \\
(0.00342)\end{array}$ & $\begin{array}{l}0.993^{* *} \\
(0.00301)\end{array}$ \\
\hline E-mail Communication & $\begin{array}{l}2.889^{* * *} \\
(0.567)\end{array}$ & $\begin{array}{l}4.393^{* * *} \\
(0.914)\end{array}$ & $\begin{array}{l}1.688^{* * *} \\
(0.252)\end{array}$ \\
\hline Managerial Experience & $\begin{array}{l}0.990 \\
(0.0109)\end{array}$ & $\begin{array}{l}1.032^{* * *} \\
(0.00924)\end{array}$ & $\begin{array}{l}1.009 \\
(0.00793)\end{array}$ \\
\hline Women-owned SME & $\begin{array}{l}0.891 \\
(0.157)\end{array}$ & $\begin{array}{l}1.104 \\
(0.187)\end{array}$ & $\begin{array}{l}1.460^{* * *} \\
(0.198)\end{array}$ \\
\hline $\begin{array}{l}N \\
\text { chi2 } \\
\text { pr2 }\end{array}$ & $\begin{array}{l}1448 \\
68.30 \\
0.0780\end{array}$ & $\begin{array}{l}1400 \\
169.2 \\
0.1692\end{array}$ & $\begin{array}{l}1376 \\
102.2 \\
0.0669\end{array}$ \\
\hline
\end{tabular}

$* \mathrm{p}<0.10, * * \mathrm{p}<0.05, * * * \mathrm{p}<0.01$

Dependent variables: current/savings account; overdraft facility; loans/lines of credit Exponentiated coefficients (odds-ratio)

Robust standard errors in parentheses 


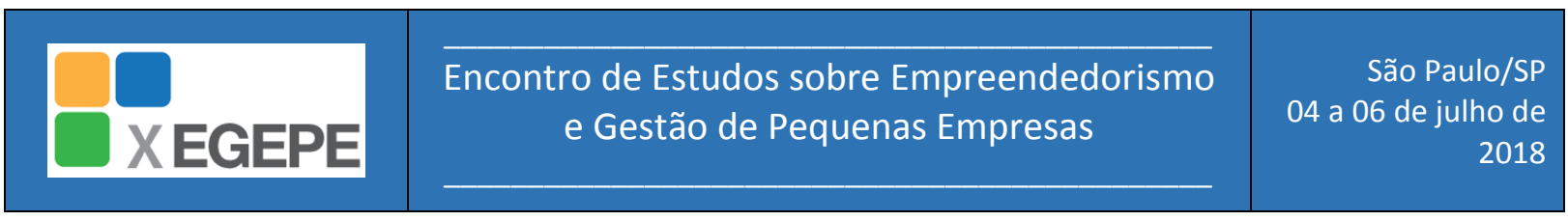

Table 4: The Impact of Mobile Money Use on Financial Inclusion: Employees and Suppliers Payments

\begin{tabular}{|c|c|c|c|c|c|c|}
\hline & \multicolumn{3}{|c|}{ Mobile Money Use to Pay Employees } & \multicolumn{3}{|c|}{ Mobile Money Use to Pay Suppliers } \\
\hline & $\begin{array}{l}\text { Checking or } \\
\text { Savings } \\
\text { Account }\end{array}$ & $\begin{array}{l}\text { Overdraft } \\
\text { Facility }\end{array}$ & $\begin{array}{l}\text { Bank Loans or } \\
\text { Lines of Credit }\end{array}$ & $\begin{array}{l}\text { Checking or } \\
\text { Savings } \\
\text { Account } \\
\end{array}$ & $\begin{array}{l}\text { Overdraft } \\
\text { Facility }\end{array}$ & $\begin{array}{l}\text { Bank Loans or } \\
\text { Lines of Credit }\end{array}$ \\
\hline Pay Employees & $\begin{array}{l}0.684 \\
(0.206)\end{array}$ & $\begin{array}{l}1.106 \\
(0.351)\end{array}$ & $\begin{array}{l}2.070^{* * * *} \\
(0.477)\end{array}$ & & & \\
\hline Pay Suppliers & & & & $\begin{array}{l}1.484^{*} \\
(0.319)\end{array}$ & $\begin{array}{l}1.052 \\
(0.201)\end{array}$ & $\begin{array}{l}1.533^{* * *} \\
(0.236)\end{array}$ \\
\hline Certification & $\begin{array}{l}1.055 \\
(0.282)\end{array}$ & $\begin{array}{l}1.157 \\
(0.226)\end{array}$ & $\begin{array}{l}1.204 \\
(0.209)\end{array}$ & $\begin{array}{l}1.083 \\
(0.288)\end{array}$ & $\begin{array}{l}1.153 \\
(0.226)\end{array}$ & $\begin{array}{l}1.161 \\
(0.201)\end{array}$ \\
\hline$\%$ Export & $\begin{array}{l}0.996 \\
(0.00273)\end{array}$ & $\begin{array}{l}1.003 \\
(0.00269)\end{array}$ & $\begin{array}{l}1.001 \\
(0.00221)\end{array}$ & $\begin{array}{l}0.995^{*} \\
(0.00272)\end{array}$ & $\begin{array}{l}1.003 \\
(0.00270)\end{array}$ & $\begin{array}{l}1.002 \\
(0.00220)\end{array}$ \\
\hline Firm Size & $\begin{array}{l}1.563^{* * *} \\
(0.200)\end{array}$ & $\begin{array}{l}1.553^{* * *} \\
(0.156)\end{array}$ & $\begin{array}{l}1.310^{* * * *} \\
(0.115)\end{array}$ & $\begin{array}{l}1.568^{* * *} \\
(0.199)\end{array}$ & $\begin{array}{l}1.553^{* * *} \\
(0.156)\end{array}$ & $\begin{array}{l}1.335^{* * *} \\
(0.117)\end{array}$ \\
\hline Firm Age & $\begin{array}{l}1.044 \\
(0.129)\end{array}$ & $\begin{array}{l}1.315^{* *} \\
(0.177)\end{array}$ & $\begin{array}{l}1.248^{* *} \\
(0.133)\end{array}$ & $\begin{array}{l}1.039 \\
(0.129)\end{array}$ & $\begin{array}{l}1.323^{* *} \\
(0.177)\end{array}$ & $\begin{array}{l}1.258^{* *} \\
(0.134)\end{array}$ \\
\hline City $250 \mathrm{~K}$ to $1 \mathrm{mi}$ & $\begin{array}{l}0.921 \\
(0.158)\end{array}$ & $\begin{array}{l}1.109 \\
(0.189)\end{array}$ & $\begin{array}{l}1.478^{* * * *} \\
(0.201)\end{array}$ & $\begin{array}{l}0.909 \\
(0.155)\end{array}$ & $\begin{array}{l}1.109 \\
(0.189)\end{array}$ & $\begin{array}{l}1.476^{* * *} \\
(0.201)\end{array}$ \\
\hline City $50 \mathrm{~K}$ to $250 \mathrm{~K}$ & $\begin{array}{l}2.013 \\
(2.052)\end{array}$ & $\begin{array}{l}1.393 \\
(1.317)\end{array}$ & $\begin{array}{l}0.235 \\
(0.238)\end{array}$ & $\begin{array}{l}1.865 \\
(2.079)\end{array}$ & $\begin{array}{l}1.469 \\
(1.351)\end{array}$ & $\begin{array}{l}0.363 \\
(0.368)\end{array}$ \\
\hline Foreign Ownership & $\begin{array}{l}0.999 \\
(0.00445)\end{array}$ & $\begin{array}{l}0.994^{*} \\
(0.00338)\end{array}$ & $\begin{array}{l}0.992^{* * *} \\
(0.00302)\end{array}$ & $\begin{array}{l}0.999 \\
(0.00450)\end{array}$ & $\begin{array}{l}0.994^{*} \\
(0.00338)\end{array}$ & $\begin{array}{l}0.992^{* *} \\
(0.00301)\end{array}$ \\
\hline E-mail Communication & $\begin{array}{l}2.981^{* * *} \\
(0.586)\end{array}$ & $\begin{array}{l}4.417^{* * *} \\
(0.920)\end{array}$ & $\begin{array}{l}1.700^{* * *} \\
(0.253)\end{array}$ & $\begin{array}{l}2.914^{* * *} \\
(0.574)\end{array}$ & $\begin{array}{l}4.417^{* * *} \\
(0.917)\end{array}$ & $\begin{array}{l}1.694^{* * *} \\
(0.253)\end{array}$ \\
\hline Managerial Experience & $\begin{array}{l}0.990 \\
(0.0109)\end{array}$ & $\begin{array}{l}1.033^{* * *} \\
(0.00912)\end{array}$ & $\begin{array}{l}1.010 \\
(0.00784)\end{array}$ & $\begin{array}{l}0.989 \\
(0.0109)\end{array}$ & $\begin{array}{l}1.033^{* * *} \\
(0.00913)\end{array}$ & $\begin{array}{l}1.009 \\
(0.00796)\end{array}$ \\
\hline Women-Owned SME & $\begin{array}{l}0.900 \\
(0.159)\end{array}$ & $\begin{array}{l}1.121 \\
(0.188)\end{array}$ & $\begin{array}{l}1.449^{* * * *} \\
(0.196)\end{array}$ & $\begin{array}{l}0.883 \\
(0.155) \\
\end{array}$ & $\begin{array}{l}1.126 \\
(0.189)\end{array}$ & $\begin{array}{l}1.468^{* * * *} \\
(0.199) \\
\end{array}$ \\
\hline $\begin{array}{l} \\
\text { chi2 } \\
\text { pr2 }\end{array}$ & $\begin{array}{l}1447 \\
70.65 \\
0.0721\end{array}$ & $\begin{array}{l}1399 \\
165.6 \\
0.1661\end{array}$ & $\begin{array}{l}1376 \\
98.47 \\
0.0655\end{array}$ & $\begin{array}{l}1448 \\
69.65 \\
0.0740\end{array}$ & $\begin{array}{l}1400 \\
163.6 \\
0.1660\end{array}$ & $\begin{array}{l}1376 \\
97.19 \\
0.0644\end{array}$ \\
\hline
\end{tabular}

$* \mathrm{p}<0.10, * * \mathrm{p}<0.05, * * * \mathrm{p}<0.01$

Dependent variables: current/savings account; overdraft facility; loans/lines of credit

Exponentiated coefficients (odds-ratio)

Robust standard errors in parentheses 
Table 5: The Impact of Mobile Money Use on Financial Inclusion: Utility Payments and Customer Revenue

\begin{tabular}{|c|c|c|c|c|c|c|}
\hline & \multicolumn{3}{|c|}{ Mobile Money Use to Pay Utilities } & \multicolumn{3}{|c|}{ Mobile Money Use to Receive Customer Payments } \\
\hline & $\begin{array}{l}\text { Checking or } \\
\text { Savings } \\
\text { Account }\end{array}$ & $\begin{array}{l}\text { Overdraft } \\
\text { Facility }\end{array}$ & $\begin{array}{l}\text { Bank Loans or } \\
\text { Lines of Credit }\end{array}$ & $\begin{array}{l}\text { Checking or } \\
\text { Savings } \\
\text { Account } \\
\end{array}$ & $\begin{array}{l}\text { Overdraft } \\
\text { Facility }\end{array}$ & $\begin{array}{l}\text { Bank Loans or } \\
\text { Lines of Credit }\end{array}$ \\
\hline Pay Utility & $\begin{array}{l}2.150^{* * * *} \\
(0.551)\end{array}$ & $\begin{array}{l}1.385^{*} \\
(0.268)\end{array}$ & $\begin{array}{l}1.652^{* * * *} \\
(0.260)\end{array}$ & & & \\
\hline Customer Payment & & & & $\begin{array}{l}1.608^{* *} \\
(0.310)\end{array}$ & $\begin{array}{l}1.538^{* * *} \\
(0.262)\end{array}$ & $\begin{array}{l}1.454^{* * * *} \\
(0.202)\end{array}$ \\
\hline Quality Certification & $\begin{array}{l}1.050 \\
(0.281)\end{array}$ & $\begin{array}{l}1.122 \\
(0.219)\end{array}$ & $\begin{array}{l}1.137 \\
(0.195)\end{array}$ & $\begin{array}{l}1.157 \\
(0.312)\end{array}$ & $\begin{array}{l}1.192 \\
(0.234)\end{array}$ & $\begin{array}{l}1.207 \\
(0.208)\end{array}$ \\
\hline$\%$ Export Sales & $\begin{array}{l}0.996 \\
(0.00271)\end{array}$ & $\begin{array}{l}1.004 \\
(0.00272)\end{array}$ & $\begin{array}{l}1.003 \\
(0.00219)\end{array}$ & $\begin{array}{l}0.996 \\
(0.00275)\end{array}$ & $\begin{array}{l}1.004 \\
(0.00274)\end{array}$ & $\begin{array}{l}1.003 \\
(0.00219)\end{array}$ \\
\hline Firm Size & $\begin{array}{l}1.600^{* * *} \\
(0.203)\end{array}$ & $\begin{array}{l}1.571^{* * *} \\
(0.158)\end{array}$ & $\begin{array}{l}1.329^{* * *} \\
(0.117)\end{array}$ & $\begin{array}{l}1.611^{* * *} \\
(0.210)\end{array}$ & $\begin{array}{l}1.588^{* * *} \\
(0.160)\end{array}$ & $\begin{array}{l}1.334^{* * *} \\
(0.117)\end{array}$ \\
\hline Firm Age & $\begin{array}{l}1.041 \\
(0.130)\end{array}$ & $\begin{array}{l}1.334^{* *} \\
(0.179)\end{array}$ & $\begin{array}{l}1.268^{* *} \\
(0.135)\end{array}$ & $\begin{array}{l}1.032 \\
(0.130)\end{array}$ & $\begin{array}{l}1.330^{* * *} \\
(0.180)\end{array}$ & $\begin{array}{l}1.265^{* *} \\
(0.134)\end{array}$ \\
\hline City $250 \mathrm{~K}$ to $1 \mathrm{mi}$ & $\begin{array}{l}0.965 \\
(0.166)\end{array}$ & $\begin{array}{l}1.135 \\
(0.194)\end{array}$ & $\begin{array}{l}1.540^{* * * *} \\
(0.211)\end{array}$ & $\begin{array}{l}0.972 \\
(0.170)\end{array}$ & $\begin{array}{l}1.136 \\
(0.195)\end{array}$ & $\begin{array}{l}1.528^{* * *} \\
(0.208)\end{array}$ \\
\hline City $50 \mathrm{~K}$ to $250 \mathrm{~K}$ & $\begin{array}{l}1.773 \\
(1.879)\end{array}$ & $\begin{array}{l}1.394 \\
(1.260)\end{array}$ & $\begin{array}{l}0.318 \\
(0.300)\end{array}$ & $\begin{array}{l}1.905 \\
(2.133)\end{array}$ & $\begin{array}{l}1.478 \\
(1.495)\end{array}$ & $\begin{array}{l}0.338 \\
(0.362)\end{array}$ \\
\hline Foreign Ownership & $\begin{array}{l}1.000 \\
(0.00448)\end{array}$ & $\begin{array}{l}0.994^{*} \\
(0.00335)\end{array}$ & $\begin{array}{l}0.992^{* *} \\
(0.00298)\end{array}$ & $\begin{array}{l}0.999 \\
(0.00446)\end{array}$ & $\begin{array}{l}0.995 \\
(0.00341)\end{array}$ & $\begin{array}{l}0.992^{* *} \\
(0.00301)\end{array}$ \\
\hline E-mail & $\begin{array}{l}2.894^{* * * *} \\
(0.569)\end{array}$ & $\begin{array}{l}4.386^{* * *} \\
(0.914)\end{array}$ & $\begin{array}{l}1.675^{* * * *} \\
(0.250)\end{array}$ & $\begin{array}{l}2.890^{* * * *} \\
(0.572)\end{array}$ & $\begin{array}{l}4.280^{* * * *} \\
(0.891)\end{array}$ & $\begin{array}{l}1.647^{* * *} \\
(0.246)\end{array}$ \\
\hline Manager Experience & $\begin{array}{l}0.991 \\
(0.0109)\end{array}$ & $\begin{array}{l}1.033^{* * *} \\
(0.00915)\end{array}$ & $\begin{array}{l}1.010 \\
(0.00787)\end{array}$ & $\begin{array}{l}0.989 \\
(0.0108)\end{array}$ & $\begin{array}{l}1.033^{* * *} \\
(0.00925)\end{array}$ & $\begin{array}{l}1.009 \\
(0.00789)\end{array}$ \\
\hline Women-Owned SME & $\begin{array}{l}0.879 \\
(0.154)\end{array}$ & $\begin{array}{l}1.107 \\
(0.186)\end{array}$ & $\begin{array}{l}1.457^{* * * *} \\
(0.196)\end{array}$ & $\begin{array}{l}0.864 \\
(0.151)\end{array}$ & $\begin{array}{l}1.089 \\
(0.184)\end{array}$ & $\begin{array}{l}1.450^{* * *} \\
(0.196)\end{array}$ \\
\hline$N$ & 1444 & 1398 & 1375 & 1446 & 1400 & 1375 \\
\hline chi2 & 75.75 & 167.8 & 96.68 & 69.89 & 165.7 & 95.04 \\
\hline pr2 & 0.0799 & 0.1684 & 0.0656 & 0.0783 & 0.1711 & 0.0640 \\
\hline
\end{tabular}

$* \mathrm{p}<0.10, * * \mathrm{p}<0.05, * * * \mathrm{p}<0.01$

Dependent variables: current/savings account; overdraft facility; loans/lines of credit

Exponentiated coefficients (odds-ratio)

Robust standard errors in parentheses 